\title{
An examination of the heat treatment effect on mechanical properties of twin-roll cast followed by cold rolling sheets made of aluminium and its alloys
}

\author{
Badania wpływu obróbki cieplnej \\ na własności mechaniczne blach z aluminium i jego stopów \\ walcowanych na zimno z wsadu twin-roll casting
}

\begin{abstract}
Modern aluminium alloys are more commonly used in various industries. Often the products of such materials operate at elevated temperatures. In addition to standard requirements in terms of mechanical and technological properties, one of the key performance properties becomes the increased resistance to annealing. This paper examines the heat treatment effect on the mechanical properties of sheets made of aluminium with grain refiner additions $(\mathrm{Ti}+\mathrm{B}), \mathrm{Fe}, \mathrm{Si}$ and $\mathrm{Mn}$.

Tested materials were obtained by cold-rolling strips, manufactured by twin-roll casting - TRC method. TRC method is increasingly being used in the manufacture of flat-rolled products. This technology eliminates the hot rolling operations and the strip obtained by TRC method can be subjected to direct cold rolling.
\end{abstract}

Keywords: aluminium, heat treatment, twin-roll casting, cold rolling

\section{Streszczenie}

Nowoczesne stopy aluminium znajdują coraz szersze zastosowanie w różnych dziedzinach przemysłu. Niejednokrotnie wyroby z takich materiałów pracują w podwyższonych temperaturach. Obok standardowych wymagań w zakresie własności mechanicznych i technologicznych jedną z kluczowych własności użytkowych staje się podwyższona odporność cieplna. W pracy przebadano wpływ obróbki cieplnej na własności mechaniczne blach z aluminium z dodatkami rozdrabniacza ziarna $(\mathrm{Ti}+\mathrm{B})$, Fe, Si oraz Mn.

Wojciech Ściężor M.Sc., Andrzej Mamala Ph.D. D.Sc., Paweł Kwaśniewski Ph.D.: AGH University of Science and Technology, Faculty of Non-Ferrous Metals, Krakow, Poland; wsciezor@agh.edu.pl, amamala@agh.edu.pl, kwas@agh.edu.pl 
Materiały poddawane badaniom wytworzono przez walcowanie na zimno taśm uzyskanych metodą twin-roll casting - TRC. Metoda TRC jest coraz częściej wykorzystywana w produkcji płaskich wyrobów walcowanych. Eliminuje ona konieczność prowadzenia walcowania na gorąco, a taśma uzyskana metodą TRC może być poddawana bezpośredniemu walcowaniu na zimno.

Słowa kluczowe: aluminium, obróbka cieplna, ciągłe odlewanie, walcowanie na zimno

\section{Introduction}

The increase in aluminium and its alloys consumption is mainly caused by economic factors and technological progress. Due to the high price of other metals (especially copper), the said materials become extremely attractive substitutes thereof. An analysis of both the scientific and branch literature shows a clear trend of the development of products made of aluminium and its alloys for electrical, construction, automotive, food, packaging and heat exchanger applications [1].

Due to the need to obtain a number of these applications at a lower cost, technologies of aluminium and its alloys processing are increasingly based on integrated processes, combining a greater number of operations in one technological line. As a result, it is possible to reduce production costs and often to omit certain stages of production. One example is increasingly used direct cold rolling of strips, obtained by twin-roll continuous casting (TRC). This technology provides a strip with the thickness between several and dozen-odd millimetres. Eliminating the whole series of operations known in the conventional technology, related to the ingot processing and the hot rolling can greatly reduce the cost of processing the material and it also reduces the investment costs [2-4].

A set of final properties of the individual product is limited by the temper and chemical composition of the material and by choosing the technological processing schedule. A very important issue, both from a technological and application point of view, is the identification and analysis of the evolution of material mechanical properties resulting from increased temperature operation. On the one hand, this parameter is the basis for the proper selection of the interoperation or the final heat treatment conditions, and on the other, it limits the operating temperature range of strainstrengthened material [5-9]. Resistance to recrystallization results not only from the type and amount of alloying additives and impurities but also from their location in the microstructure. In general, the elements locating in aluminium solid solution increase the resistance to recrystallization through their impact on the mobility of the grain boundaries and the speed of the nucleation and growth of new grains. In many cases, the effect of these elements has a synergistic nature. The effect of this elements group on the recrystallization process is limited by the rate of their diffusion in the matrix. Another mechanism of the effect on the recrystallization process is exhibited by 
elements that constitute separate phases. Large particles may facilitate the recrystallization due to the formation of areas favourable for nucleation, but very small and uniformly dispersed particles definitely hinder the reconstruction of the structure during recrystallization by dislocation binding. In the literature, one can find works indicating a higher resistance to the recrystallization of rolled materials after TRC in relation to materials manufactured by a conventional method [10]. This makes sheets rolled from the TRC raw materials not only economical but also, in many applications, a technical alternative to products manufactured in the conventional process. The heat treatment effect on the mechanical properties of sheets made of aluminium with grain refiner additions $(\mathrm{Ti}+\mathrm{B}), \mathrm{Fe}, \mathrm{Si}$ and $\mathrm{Mn}$ is a key engineering and scientific problem and it is the essence of this paper.

\section{Material and examination methods}

Trials were conducted with the use of $99.5 \%$ pure aluminium as the base material. In order to obtain appropriate alloys, alloying additions were added to the base metal in the form of special metallurgical master-alloys. Chemical compounds of the tested alloys are shown in Table 1.

Table 1. Chemical compositions of the examined materials

\begin{tabular}{|c|c|c|c|c|c|c|c|}
\hline \multirow{2}{*}{ Material } & \multicolumn{7}{|c|}{ Chemical composition [wt.\%] } \\
\cline { 2 - 8 } & Fe & Si & Cu & Zn & Mn & Ti & Al \\
\hline Al & 0.2 & 0.1 & 0.02 & 0.02 & - & - & rest \\
\hline AlTiB & 0.2 & 0.1 & 0.02 & 0.02 & - & 0.05 & rest \\
\hline AlFe & 0.8 & 0.1 & 0.02 & 0.02 & - & - & rest \\
\hline AlFeSi & 0.8 & 0.4 & 0.02 & 0.02 & - & - & rest \\
\hline AlFeMn & 0.6 & 0.1 & 0.02 & 0.02 & 1 & - & rest \\
\hline
\end{tabular}

Materials presented in Table 1 were prepared in laboratory conditions by TRC continuous casting on an original stand, which is shown in Figure 1. The casting process was carried out at a speed of $0.5 \mathrm{~m} / \mathrm{min}$. This resulted in obtaining a strip made of aluminium and its alloys with a thickness of $9 \mathrm{~mm}$ and width of $90 \mathrm{~mm}$. A general view of the strip and process is shown in Figure 2. 

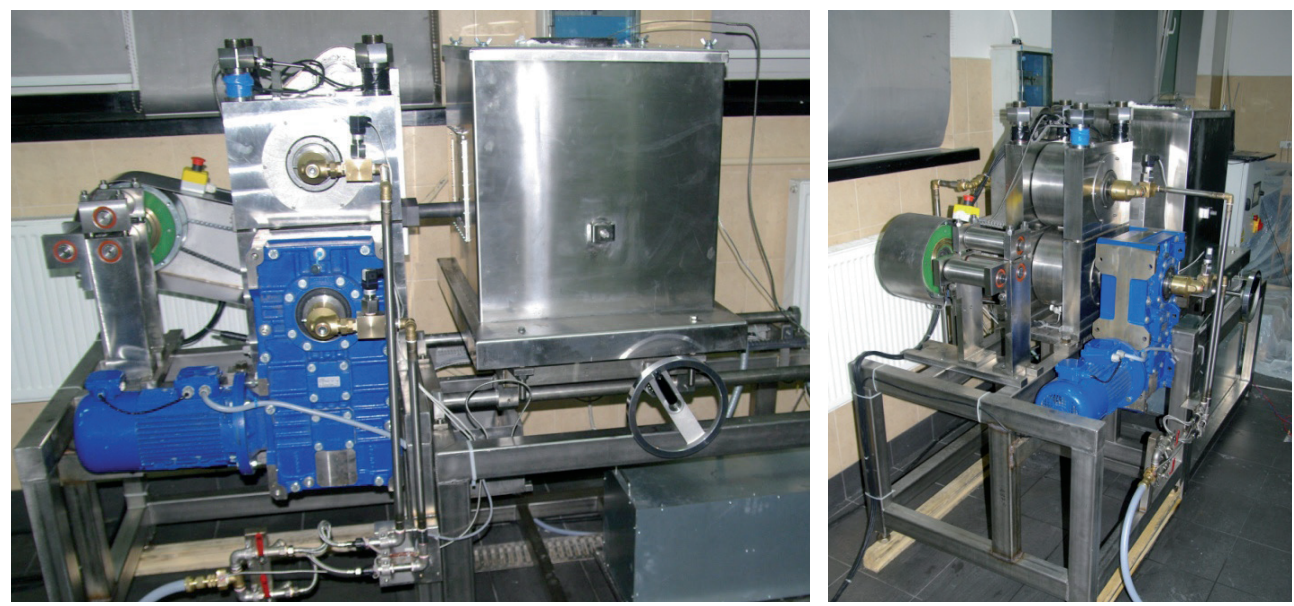

Fig. 1. Overview of laboratory twin-roll casting installation and casting process

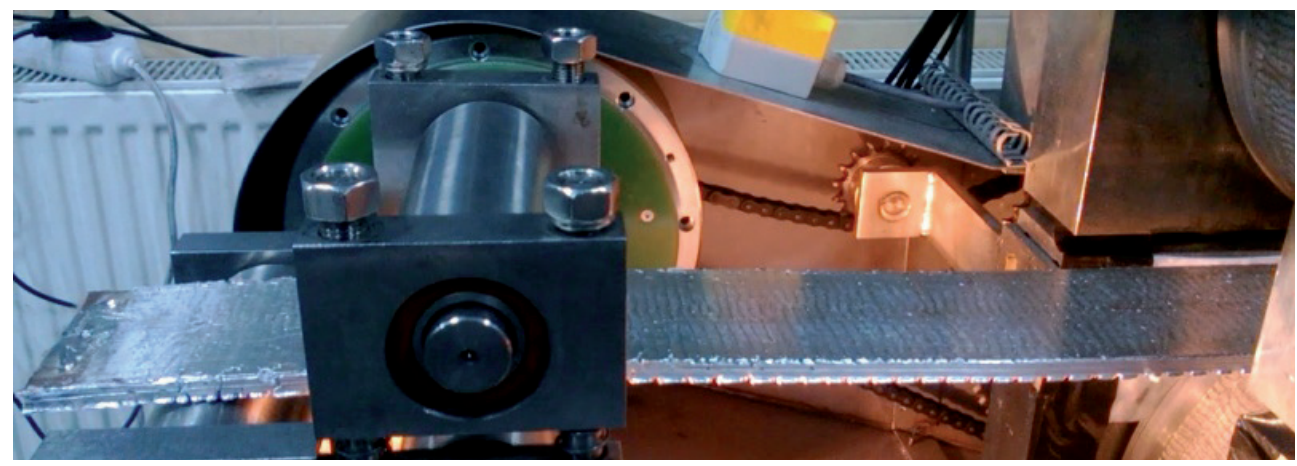

Fig. 2. Strip leaving rollers - crystallizers during continuous casting process

Materials after continuous casting were subjected to machining to obtain samples at a thickness of $9 \mathrm{~mm}$, and a width of $90 \mathrm{~mm}$, dedicated to cold rolling process. Rolling was carried out on a quarto reversing laboratory mill machine according to the following passes: $9 \mathrm{~mm}-8.3 \mathrm{~mm}-7.6 \mathrm{~mm}-6.5 \mathrm{~mm}-5.4 \mathrm{~mm}-4.5 \mathrm{~mm}-3.8 \mathrm{~mm}-3 \mathrm{~mm}$ $-2.2 \mathrm{~mm}-1.5 \mathrm{~mm}$. The rolling process was conducted at a speed of $15 \mathrm{~m} / \mathrm{min}$. Figure 3 shows the laboratory quarto reversing mill used in the experiment.

A key part of the research was to determine the actual resistance to the annealing of the tested materials. The final sheet samples with a final thickness of $1.5 \mathrm{~mm}$ after cold rolling (83\% of total strain) were subjected to heating for a period of one hour at temperatures of: $100^{\circ} \mathrm{C}, 150^{\circ} \mathrm{C}, 200^{\circ} \mathrm{C}, 250^{\circ} \mathrm{C}, 300^{\circ} \mathrm{C}, 350^{\circ} \mathrm{C}, 400^{\circ} \mathrm{C}, 450^{\circ} \mathrm{C}, 500^{\circ} \mathrm{C}$ and final hardness measurements. Materials after rolling and annealing at $400^{\circ} \mathrm{C}$ were subjected to a static tensile test for a more comprehensive assessment of their mechanical properties. 

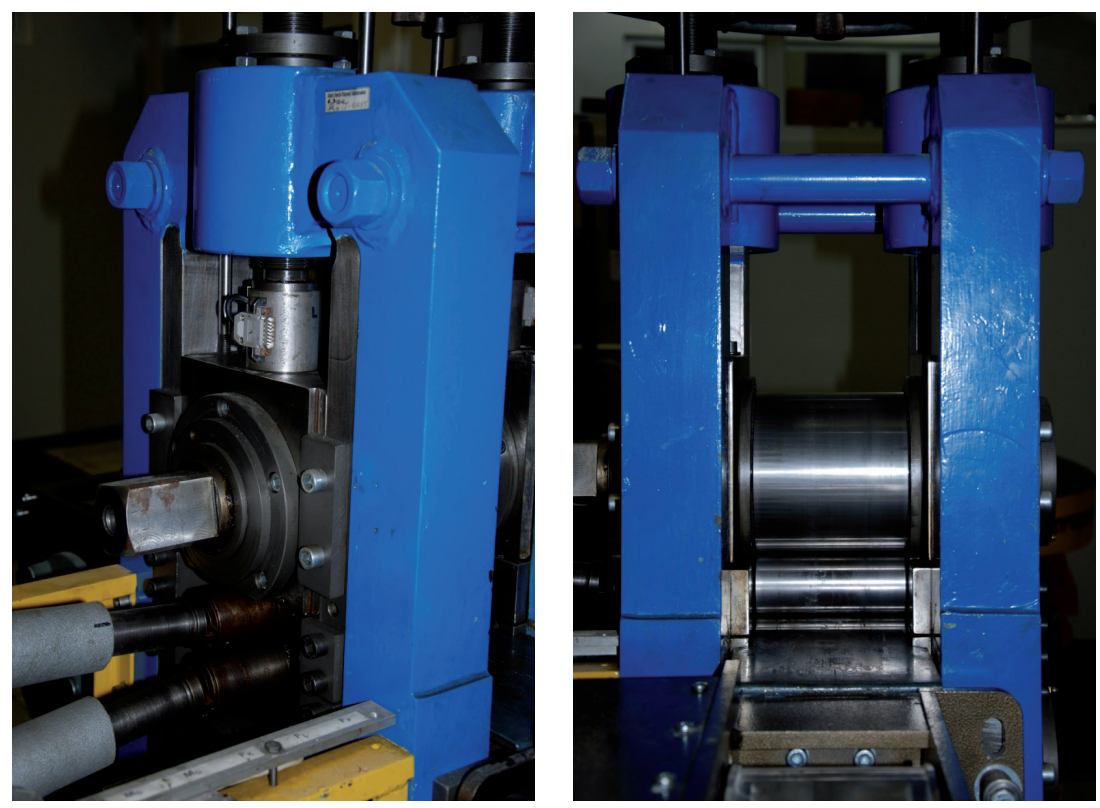

Fig. 3. General view of the laboratory reversing quarto mill

\section{Results and discussion}

Figures 4-5 show the effect of the annealing temperature after rolling on the hardness of the tested materials.

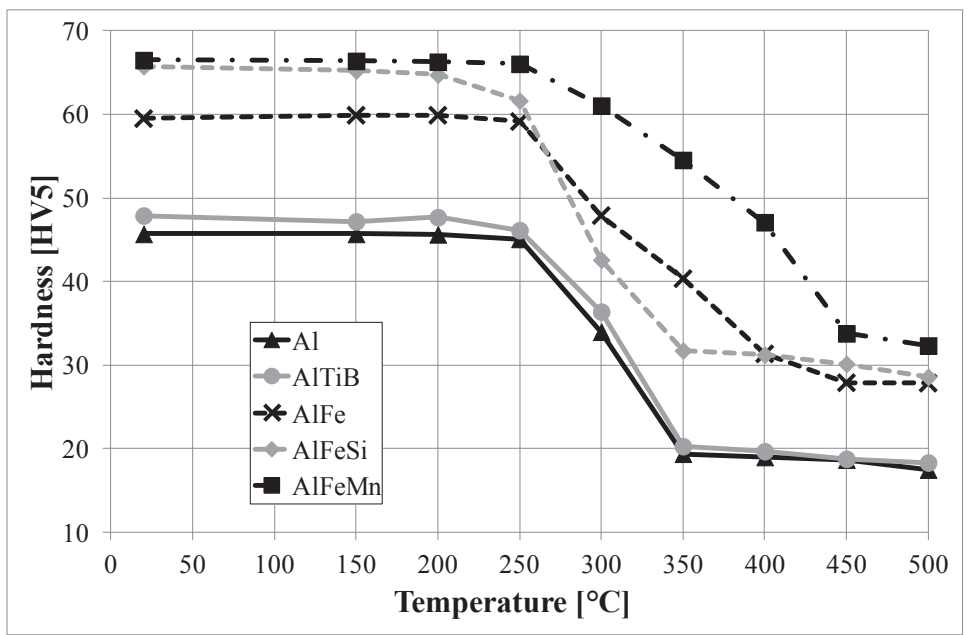

Fig. 4. Curves of the evolution of the tested materials hardness in the function of the annealing temperature, annealing time: one hour (hardness measurements at ambient temperature) 


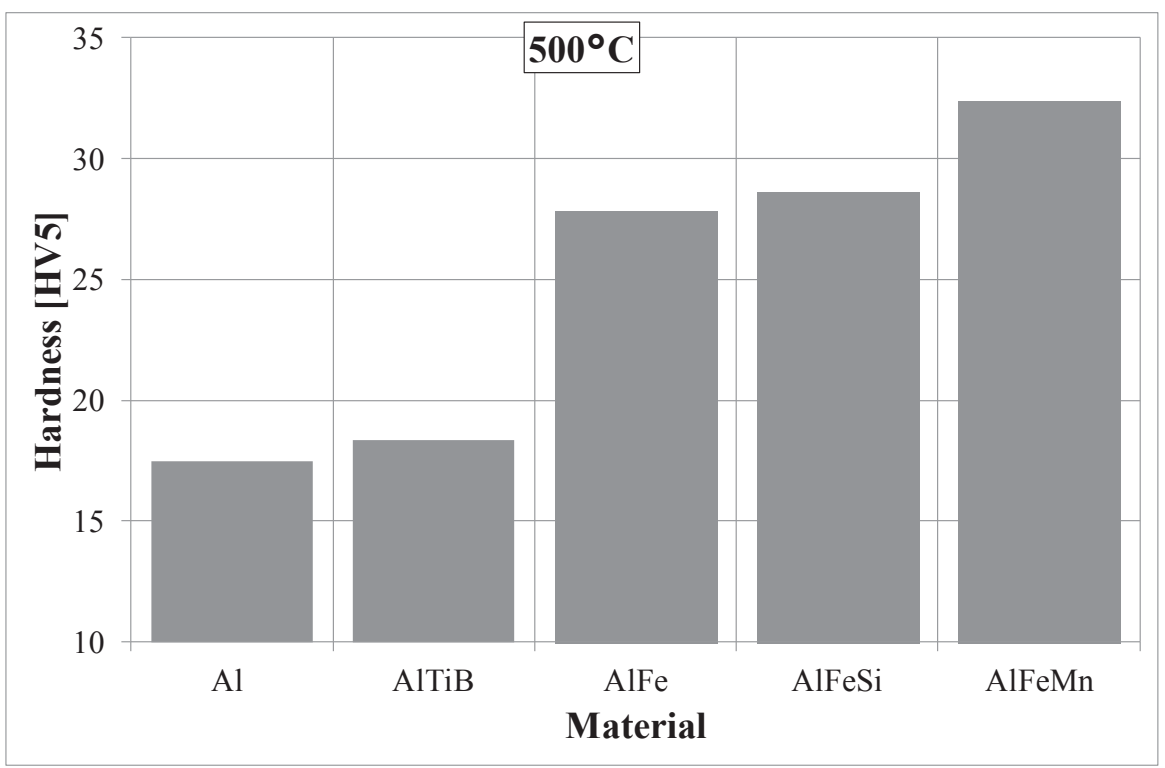

Fig. 5. Final hardness of the tested materials after annealing at $500^{\circ} \mathrm{C}$, annealing time: one hour (hardness measurements at ambient temperature)

Data for pure aluminium in Figure 4 shows that this material begins to lose its mechanical properties at a temperature of approximately $250^{\circ} \mathrm{C}$, wherein the soft material is able to be obtained already at $350^{\circ} \mathrm{C}$. Practically, aluminium with a grain refiner additive behaves in the same manner.

The addition of the iron as an alloying additive shows the loss of mechanical properties which starts almost at the same temperature as for pure aluminium (approximately $250^{\circ} \mathrm{C}$ ). The material in the soft temper is obtained at about $425^{\circ} \mathrm{C}$. It can be concluded that the addition of iron significantly increases the thermal resistance of aluminium from a TRC line.

The aluminium-iron-silicon alloy subjected to annealing loses its mechanical properties within the temperature range of $250-350^{\circ} \mathrm{C}$. In this alloy, there are no increases of the resistance to annealing observed that result from the addition of alloy additives in comparison to pure aluminium, despite the presence of iron. Probably, the presence of silicon influences the change in the nature of evolved phases.

Definitely, the addition of the iron and manganese has the highest influence on the increase of the resistance to annealing. For the examined alloy, material in the soft temper can be obtained at a temperature of $450^{\circ} \mathrm{C}$.

It should be noted that the observed increase of the fully annealed temper temperature due to additions of $\mathrm{Fe}$ and $\mathrm{Mn}$ is slightly higher than the typical values well known from the literature data presented by Belov [11]. 


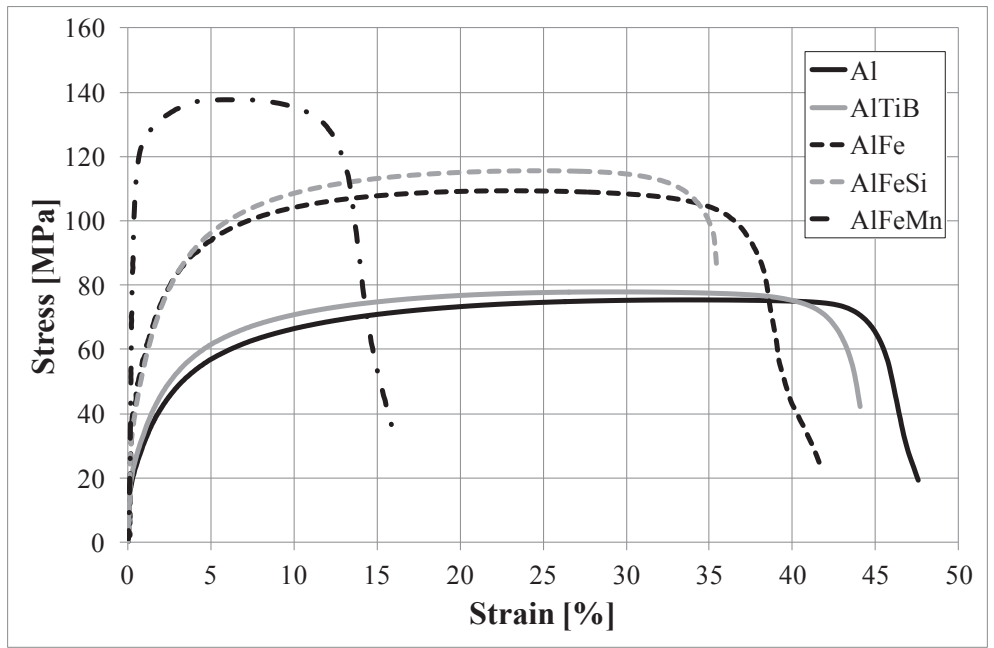

Fig. 6. Stress-strain curves from the uniaxial tensile test, materials after cold rolling and for heat treatment at $400^{\circ} \mathrm{C}$ for $1 \mathrm{~h}$

As a result of the performed research works, mechanical properties of sheets were determined after cold rolling and annealing at $400^{\circ} \mathrm{C}$ for $1 \mathrm{~h}$. The terms of annealing of all tested materials were identical (for comparative purposes). Although the selected parameters of the annealing can result in the incomplete annealing of alloys containing manganese, but on the other hand the increased temperature of the heat treatment could be risky due to the possibility of grain growth in pure aluminium (secondary recrystallization). Figure 6 shows curves: stress-strain obtained in the static tensile test of individual materials after annealing. The collective summary of the obtained properties is shown in Table 2.

Table 2. Summary of mechanical properties of the tested materials after rolling and thermal processing at $400^{\circ} \mathrm{C} / 1 \mathrm{~h}$

\begin{tabular}{|c|c|c|c|c|}
\hline Material & YS [MPa] & UTS [MPa] & A $_{30}[\%]$ & Au [\%] \\
\hline Al & 23.5 & 75.5 & 47.5 & 33.4 \\
\hline AlTiB & 26.6 & 78.0 & 44.0 & 29.1 \\
\hline AlFe & 47.4 & 109.4 & 41.6 & 22.9 \\
\hline AlFeSi & 44.8 & 115.6 & 35.4 & 24.3 \\
\hline AlFeMn & 113.0 & 137.8 & 16.1 & 6.7 \\
\hline
\end{tabular}


An analysis of a static tensile test of sheets after rolling and annealing at $400^{\circ} \mathrm{C}$ results shows that these materials can be divided into three groups. The first is the pure aluminium and aluminium modified with a AITi5B1 grain refiner. Aluminium strength properties significantly decrease in comparison to the material after the rolling process (UTS 150.0 MPa, YS - 140.9 MPa). The tensile strength of aluminium after the rolling and annealing process is $75.5 \mathrm{MPa}$ and $\mathrm{YS}$ is $23.5 \mathrm{MPa}$. These values are comparable to those, achieved by the material after casting. Aluminium modified with AlTi5B1 grain refiner after rolling and annealing shows slightly higher strength properties than pure aluminium, and it is respectively: YS - 26.6 MPa, UTS - 78 MPa (after rolling UTS - 158.3 MPa, YS - 148.7 MPa).

The second characteristic group is aluminium alloy with an iron additive and with iron and silicon additives. Despite higher strength properties (resulting from added alloy additives), these materials are obtained in a soft temper after annealing at $400^{\circ} \mathrm{C}$ for 1 hour. Aluminium with iron additive, after the rolling and annealing processes is characterized by the following mechanical properties: YS - 47.4 MPa, UTS - 109.4 MPa (after rolling UTS - 210.6 MPa, YS - 178.3 MPa). Aluminium alloy containing iron and silicon additives, subjected to the process of rolling and annealing exhibits properties that are comparable to aluminium-iron alloy.

The last one, the third group is the aluminium-iron-manganese alloy. As can be observed both from the curves of the softening and stress-strain curves from the static tensile test, this material did not yield to full recrystallization at a temperature of $400^{\circ} \mathrm{C}$. The aluminium alloy with an additive of iron and manganese shown the highest strength properties after annealing process, namely: YS - $113 \mathrm{MPa}$, UTS - $137.8 \mathrm{MPa}$ (after rolling UTS - 220.9 MPa, YS - 190 MPa). The elongations in the tensile tests after annealing confirm that materials rebuilt their plasticity after annealing.

\section{Summary}

Properties of Al sheets, cold rolled from the TRC method raw materials evolve during annealing for 1 hour within a temperature range of $250-350^{\circ} \mathrm{C}$. The aluminium with AlTi5B1 additive and AlFeSi alloy demonstrates an almost identical behaviour. On the other hand the results confirm that adding iron as the alloy additive in a two-element system increases the heat resistance. For AlFe alloy, the temperature range in which the loss of mechanical properties occurs is $250-425^{\circ} \mathrm{C}$. Definitely the highest resistance to annealing can be observed in AlFeMn, where soft material can be obtained at $450^{\circ} \mathrm{C}$.

The test results, in correlation with the literature data implies that the sheets made from the TRC raw material are characterized by increased resistance to annealing, which can be further increased by using suitable alloying additives. In addition, TRC technology makes it possible to shorten the cycle of sheet producing and to lower its energy consumption, which is effective. 


\section{References}

[1] Sanders Jr. R.E., Hollinshead P.A., Simielli E.A.: Industrial Development of Non-Heat Treatable Aluminum Alloys. Materials Forum, 28 (2004), 53-64

[2] Cook R., Grocock P.G., Thomas P.M., Edmonds D.V., Hunt J.D.: Development of the twin-roll casting process. Journal of Material Processing Technology, 55 (1995), 76-84

[3] Edmonds D.V.: Innovation in the processing of tonnage materials: examples from the steel and aluminium industries. Journal of Materials Processing Technology, 83 (1998), 1-13

[4] Ściężor W., Knych T., Mamala A.: Innowacyjna technologia odlewania stopów aluminium metodą twin-roll casting [in:] J. Juraszek, J. Kurowska-Pysz (red.): Innowacyjność akademicka akceleratorem rozwoju nauki i przedsiębiorczości. Bielsko-Biała, Wydawnictwo Naukowe Akademii Techniczno-Humanistycznej, 2012, 147-162

[5] Birol Y.: Response to annealing treatment of a twin-roll cast thin AlFeMnSi strip. Journal of Materials Processing Technology, 209 (2009), 506-510

[6] Birol Y.: Response to annealing treatments of twin-roll cast thin Al-Fe-Si strips. Journal of Alloys and Compounds, 458 (2008), 265-270

[7] Birol Y.: Interannealing twin-roll cast Al-Fe-Si strips without homogenization. Scripta Materialia, 61 (2009), 185-188

[8] Slámová M.: Effect of Strain Level on Recrystallisation Response of AA8006 and AA8011 Thin Strips. Metal (2001)

[9] Aghaie-Khafri M., Mahmudi R.: The effect of preheating on the formability of an Al-Fe-Si alloy sheet. Journal of Materials Processing Technology, 169 (2005), 38-43

[10] Kammer C., Krumnacker M., Pysz G.: Thermomechanische Behandlung von Al99,5-Gießwalzband [Thermomechanical treatment of continuously cast and rolled Al99.5 alloy]. Neue Hütte 35 (1990), 418-421

[11] Belov N.A., Aksenov A.A., Eskin D.G.: Iron in Aluminium Alloys: Impurity and Alloying Element. CRC Press, 2002 (p. 154, tab. 51) 